
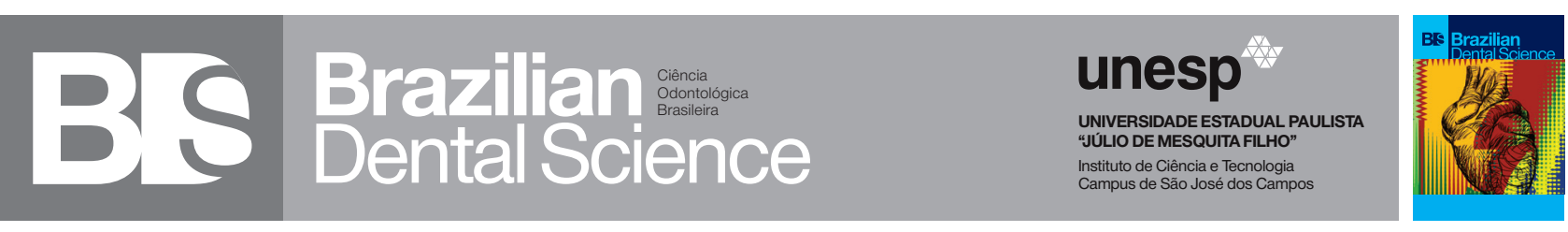

\title{
Morphological evaluation of temporo-mandibular joint in indian population
}

\author{
Avaliação morfológica da articulação temporo-mandibular em Indianos \\ Shivlal. RAWLANI ${ }^{1}$, Rahul BHOWATE ${ }^{1}$, Shivali KASHIKAR ${ }^{2}$, Monika KHUBCHANDANI ${ }^{1}$, Sudhir RAWLANI ${ }^{3}$, Rakhi CHANDAK ${ }^{4}$ \\ 1 - Department of Oral Medicine \& Radiology - SPDC,DMIMSU - Sawangi - Wardha - India. \\ 2 - Department of Radiodiagnosis - JNMC,DMIMS - DU,Sawangi - Wardha - Maharashtra - India. \\ 3 - Department of Public Health Dentistry - VSPM Dental College \& Hospital - Nagpur - Maharashtra - India. \\ 4 - Department of Oral Medicine \& Radiology - SDK Dental College - Nagpur - India.
}

\begin{abstract}
The temporomandibular joint (TMJ) is one of the most complex joints in the body and its harmonious functioning is very important to maintain a normal masticatory system. The morphologic alterations and the asymmetrical position of the TMJ structures may lead the various clinicalsigns \& symptoms. Morphology of the temporomandibular joint may be influenced by gender of patients, environmental factor and also food habits at various places. Objective: To evaluate the morphology of the temporomandibular joint using computed tomography, in order to determine the condyle shape, joint space and glenoid fossa roof thickness. Material and Methods: One hundred and six healthy patients (212 TMJs) who visited a private hospital (or the University's Hospital) for CT brain scan were included to this crosssectional study sample.The patients were aged between $20-50$ years with an average age of 35.46 years. All the images were taken by positioning patients in supine position with $120 \mathrm{kvp}$, 50ma,2.33minute exposure with $0.7 \mathrm{~mm}$ thick slicesby computed topography machine in all three projection that is Axial, Coronal and Saggital view. Results: For all variables, the mean and standard deviation were calculated, based on gender, and TMJ sides. The Paired t-test was used and $\mathrm{P}<0.05$ will be considered to be significant. Conclusion: Present study showed that thereis positive evidence of temporomandibular joint involvement in elderly patients. Change in morphology and position of condylar head with glenoid fossa and roof thickness are one of the most common cause of degenerative diseases.
\end{abstract}

\section{KEYWORDS}

Temporomandibular joint; Morphology; Condyle; Joint space.

\section{RESUMO}

Objetivo: A articulação temporomandibular (ATM) é uma das articulações mais complexas do corpo e seu funcionamento harmonioso é muito importante para manter um sistema mastigatório. As alterações morfológicas e a posição assimétrica das estruturas da ATM podem levar os vários sinais e sintomas clínicos. A morfologia da articulação temporomandibular pode ser influenciada pelo gênero dos pacientes, fatores ambientais e também hábitos alimentaresdiversos. Objetivo: Avaliar a morfologia da articulação temporomandibular usando tomografia computadorizada, a fim de determinar a forma do côndilo, o espaço articular, e a espessura do teto da fossa glenóide. Material e Métodos: Cento e seis pacientes saudáveis (212 ATMs) que foram a um hospital privado (ou Hospital da Universidade) para tomografia computadorizada de cérebro foram incluídos na amostra deste estudo transversal. Os pacientes tinham entre 20 e 50 anos com uma idade média de 35,46 anos. Todas as imagens foram tiradas com os pacientes posicionados em decúbito dorsal com 120kvp, 50mA, 2,33minutos de exposição com espessura de $0.7 \mathrm{~mm}$ nas três projeções: Axial, Coronal e Saggital. Resultados: Para todas as variáveis, a média e desvio padrão foram calculados, com base no sexo e nos lados da ATM. O teste t pareado foi usado e $\mathrm{P}<0,05$ foi considerado significativo. Conclusão: $\mathrm{O}$ presente estudo mostrou que há evidências positivas de envolvimento da articulação temporomandibular nos pacientesmais velhos. Mudança na morfologia e posição da cabeça condilar com a espessura do teto da fossa glenóide é uma das causas mais comuns de doenças degenerativas.

\section{PALAVRAS-CHAVE}

Articulação temporomandibular; Morfologia; Côndilo; Espaço articular. 


\section{INTRODUCTION}

$\mathrm{T}$ he tempromandibular joint is a ginglymodiarthroidal type of joint which consists of the glenoid fossa, articular eminances, the mandibular condyle and the articular disc which are enclosed within a fibrous capsule and the joint is stabilized by the extracapsular tempromandibular and sphenomandibular ligament.[1]The TMJ is capable of producing a variety of movements like opening, closing, lateral and translatory movements. This is possible due to the coordination between the various muscles, ligaments and the associated movements of the condyle. The human condyle has a capacity for remodeling. [2] which are influenced by a variety of factors which can result in morphological diversity and variations in shape. Several studies have dealt with the position of the condyle but not much emphasis has been laid on the shape of the condyle.[3].

The temporomandibular joint (TMJ) is one of the most complex joints in the body and its harmonious functioning is very important to maintain a normal masticatory system. The morphologic alterations and the asymmetrical position of the TMJ structures may be influenced by different factors, such as dental absence, abrasion, premature contacts, parafunction, unilateral crossbite and dentoskeletal asymmetries. [4-6]

Although there are studies showing how joint characteristics relate to facial morphology, [5,7] data are sparse and most studies focus mainly on the position of the condyle in the mandibular fossa, without mentioning its morphology. Conversely, several studies have evaluated condylar concentricity on tomographic scans, by using both symptomatic and/or asymptomatic samples,[8-11] normal occlusion,[12] different modalities of malocclusion.[4,13-16] Despite the numerous studies, the condylar position in the population remains a controversial topic.
Temporomandibular Joint is one of the most important and unique joints in the body(TMJ). TMJ is a freely movable articulation between the condyle of the mandible and squamous portion of the temporal bone at the base of the skull. [17]

The shape and size of the mandibular condyle varies greatly among different age groups and individuals. Morphologic changes may occur on the basis of simple developmental variability as well as remodeling of condyle to accommodate developmental variations, malocclusion, trauma and other developmental abnormalities and diseases.[18-20]

Mandibular condyle varies considerably both in size and shape. When viewed from above, the condyle is roughly ovoid in outline. It is 15 to $20 \mathrm{~mm}$ side to side and 8 to $10 \mathrm{~mm}$ from front to back. [19] There is great variation in the size and shape of the components of the temporomandibular joint, and its relationship to each other. In most of the study conducted on morphology of condylar head found that the normal condylar head must have a convex configuration throughout and that symmetry should exist between contra-lateral sides in the same individual.TMJ morphology has been studied on dry and autopsy human skulls, histology, radiographic exams, magnetic resonance, computed tomography and ConeBeam Computed Tomography (CBCT) methods. [21]

In 1960s and 1970s studies were performed mainly on dry skulls and autopsy materials. [2224] These studies used macroscopic observations, radiological cephalometry and tomography. In 1961, Yale et al. was the first one to report about the different shapes of mandibular condyle.[22] Initially Yale classified condylar head based on superior view into three categories namely concave, convex and flat, however later on he simplified it into four categories namely convex, flattened, angled and rounded.[22,23,25] 
A study in 1980's on mandibular condyle morphology in relation to malocclusion in children revealed that the condylar size in males was greater than in females and midline discrepancy significantly altered the increase in condylar size during growth[26,27].

The ideal position of the mandibular condyle in the glenoid fossa with an established occlusion has been a source of interest and controversy over the years.[28] Some studies have shown a significant correlation between these variables,[29-33] whereas others reported no relationship between them in different kinds of malocclusion and suggested that the asymmetric position of the condyles could be a characteristic of the normal population. $[33,35]$

The glenoid fossa, located at the inferior aspect of the squamous part of temporal bone, is composed of the glenoid fossa and articular eminence of the temporal bone. It is sometimes described as the temporal component of the TMJ. The articular eminence forms the anterior limit of the glenoid fossa and is convex in shape. [36] The articular eminence is a part of the temporal bone onwhich the condylar process slides during mandibular movements. The inclination of articular eminence varies among people and it dictates the path of condylar movement as well as the degree of rotation of the disc over the condyle.[37,38]

The thickness of the roof of the glenoid fossa (RGF) of the TMJ was assessed in previous studies related to gender, age, and condyle morphology.[39-41]Tsuruta et al. suggested that compensative bone formation in the RGF might help to withstand the increased stress in the TMJ accompanying condylar bone change, especially erosion.[42] The changes of osteoarthritis seen in the TMJ, such as erosion, articular surface remodelling and flattening, and osteophytes, are identical to those seen in other affected joints.

The temporomandibularjoint is located between the mandibular condyle and the temporal bone. $[43,44]$ The radiographic joint space is a radiolucent area between the mandibular condyle andthe temporal bone. [45] Joint space measurements were introduced by Ricketts to describe condylar position. [46]

The clinical significance of condyle-fossa relationships in the temporomandibular joint is a matter of controversy.[47] Some studies have suggested an association between eccentric condylar position and temporomandibular disorder.[48-51] These studies have suggested therapeutic procedures to optimize the condylar position in some patients.[48,51,52] However, other studies failed to demonstrate significant association between the condylar positioning and the incidence of TMD. [54,55]

In 1960s and 1970s studies were performed mainly on dry skulls and autopsy materials. [2224]These studies used macroscopic observations, radiological cephalometry and tomography. In 1961, Yale.S.H et al. was the first one to report about the different shapes of mandibular condyle,futher he classified condylar head based on superior view into three categories namely concave, convex and flat, however later on he simplified it into four categories namely convex, flattened, angled and rounded.[22]

A study conducted by Tadej $G$ et.al.in 1987 on mandibular condyle morphology in relation to malocclusion in children revealed that the condylar size in males was greater than in females and midline discrepancy significantly altered the increase in condylar size during growth.[26]

Most of the study conducted on morphological evaluation of TMJ are conducted on oversee population and not included all morpho-metric measurements of condylar head, very few study conducted on Indian population. Considering all these things we consider present study for morphological evaluation of TMJ in Indian population. 


\section{METHODS AND MATERIALS}

After obtaining the approval from ethics committee approval and informed consent from the patients, Total of 106 healthy patients (212joints) who visited to our hospital for CT Brain were included in the present crosssectional study. All CT images were taken following a standardized protocol for patient positioning and exposure parameter setting.

The patients were aged between 20-50 years with an average age of 35.46 years. For each patient, both the right and left side images were taken, therefore the total number of TMJ images studied was 212 .

The study was designed to analyze metrically the morphology of the condyle and glenoid fossa, which included the condylar size (length, width and height), thickness of the glenoid fossa roof, position of the condyle. The methodology used in this study to measure the size of the condyle was described by Hilgers ML. [56]

All the images were taken by putting patients in supine position with $120 \mathrm{kvp}$, 50ma,2.33minute exposure with $0.7 \mathrm{~mm}$ thick slices multi-dictator computed topography machine. Area is view from vertex to base of skull by using all three projection that is Axial, Coronal and Saggital view.

A two-dimensional sagittal slice was selected in which the condyle and glenoid fossa were clearly noticed. From this slice the condylar length was measured. (Figure 1) The condylar length was measured from the line extending from the posterior mandibular condyle point (PCo) to the anterior mandibular condyle point (ACo). Both these points are located $4 \mathrm{~mm}$ inferior to the superior mandible condyle (SCo) on either side of the condyle.

Condylar height was measured as a perpendicular linear distance from superior mandible condyle (SCo) to a line constructed between the most inferior point of the sigmoid notch (InfSig) perpendicular to the tangent of the posterior surface of the ramus in the sagittal plane (Figure 2). Condylar width that is linear distance between the medial and lateral poles of mandible, was measured in the coronal plane (Figure 3)

The thinnest bone forming the roof of the glenoid fossa (RGF) was identified and measured in the sagittal plane as per the protocol defined by Hegde S, in 2013. [57], (Figure 2). Joint space is used to determine the position of the condyle in glenoid fossa. The landmarks and linear measurements of the space between the condyle and the glenoid fossa were determined by using the parameter defined by Ikeda K, Kawamura A. in 2009. [9] The true horizontal line (THL) which is tangential to the roof of the glenoid fossa was used as the reference plane. The superior space (SS) was measured as a distance from the superior condyle (SCo) (most superior condyle point) to the superior fossa (Figure 4)

In order to measure the anterior and posterior spaces, the line tangent to the most prominent anterior and posterior aspects of the condyle was drawn from the SF. The distance from the anterior condyle (AC) to the corresponding glenoid fossa bone was measured as the anterior space (AS) and from the posterior condyle (PC) to the corresponding glenoid fossa bone was measured as the posterior space (PS) (Figure 4).

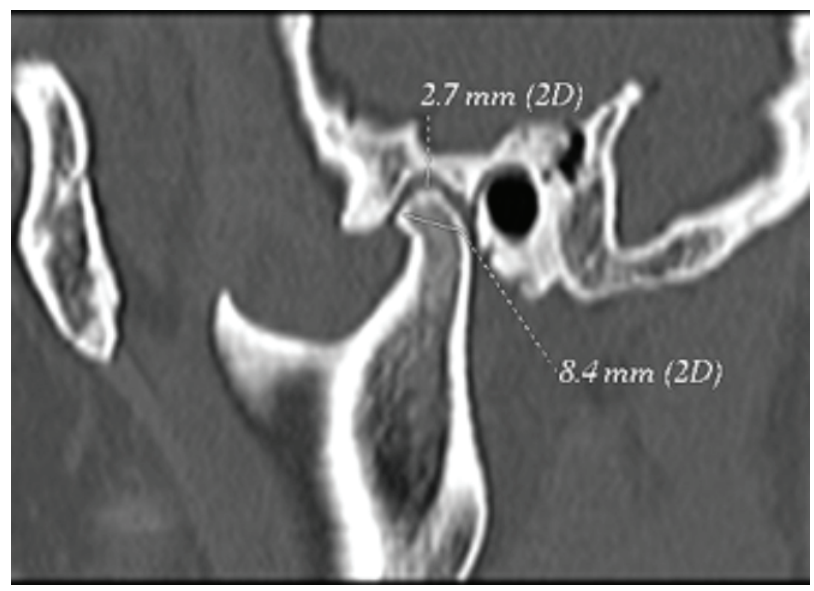

Figure 1 - CT. Saggital view showing Condylar length and superior joint space. 


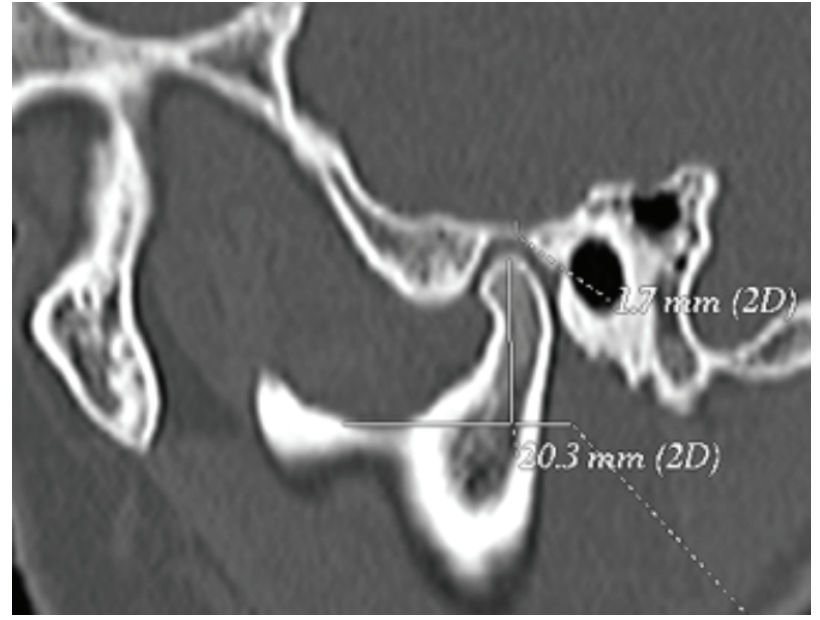

Figure 2 - CT. Saggital view showing Roof Thickness and condylar Height measurement.

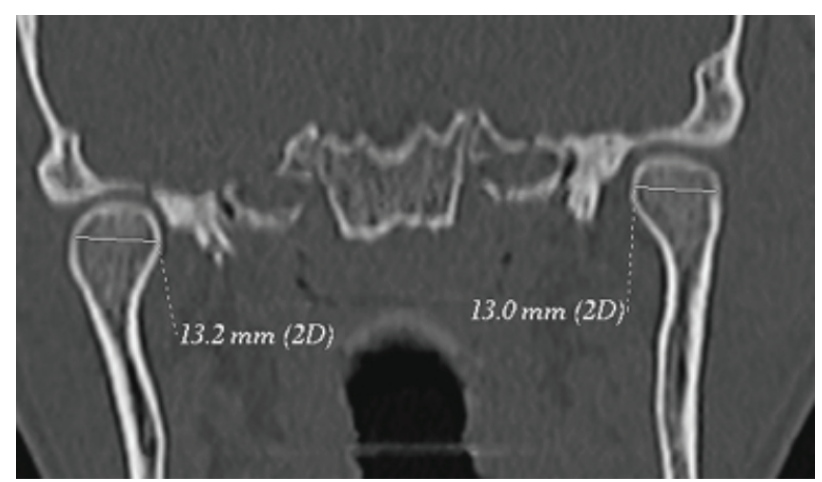

Figure 3 - CT. Coronal view showing Condylar width measurement.

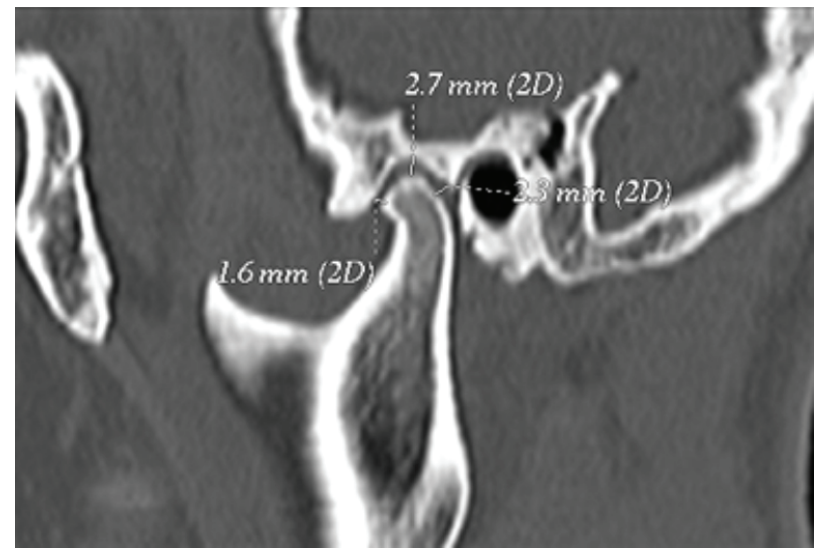

Figure 4 - CT. Saggital view showing Joint Space measurements

\section{Inclusion Criteria:} of Brain.

Patients who have came for CT Imaging

Patients who are willing to participate

Age group 20 to 50 years.

\section{Exclusion Criteria:}

Patients with past history of trauma

Patients not willing to participate

Patients already receiving treatment for TMJ disorders

Patients below 20 yrs of age and above 50 yrs of age

\section{Statistical Analysis:}

The measurements were processed and analyzed using SPSS 20.0. For all variables, the mean and standard deviation were calculated, based on gender, and TMJ sides .The distribution of quantitative variables (condylar size, condylar volume, thickness of RGF, AS, PS, and SS) was examined for normality using the Shapiro-Wilk test before analysis. The Independent t-test was used where appropriate to examine the difference in mean between gender (male and female).

The Paired t-test was used where appropriate to examine the difference between the right and left sides. $\mathrm{P}<0.05$ will be considered to be significant.

Results \& Observations:

Total 106 patients (212 joints) were included in present study.Outoff 106 patients 53 male \& 53 were female with mean age for male was as $36.04 \pm 10.95$ years and for female mean age was as $34.89 \pm 1104$. (Table 1)

There was no significant difference between genders when anterior joint space 
(AS), superior joint space (SS), and posterior joint space (PS) of right TMJ were compared but when left TMJ was compared between gender only superior joint space show significant difference with p value of 0.039 (Table 2).

There was no significant difference between males and females when condylar length, height and roof thickness of right TMJ was compared. In addition, the mean values of condylar length, height and roof thickness in males were higher compared to females. But there was significant difference between males and females when condylar width of right TMJ was compared with left TMJ $(\mathrm{P}=0.038)$. (Table 3$)$

There was no significant difference between males and females when condylar length, height and roof thickness of left TMJ was compared. he mean values of condylar length and height in males were higher compared to females. But there was significant difference between males and females when condylar width and roof thickness of left TMJ was compared with p-value of 0.024 and 0.040 respectively. (Table 3)

Posterior joint space show significant differences between the right and left side with p-value of 0.04 but at the same time anterior and superior joint spaces show no significant difference between the right and left sides. (Table 4)

There was no significant difference between right and left TMJ when condylar width and roof thickness was compared. But there was significant difference between right and left TMJ.Condylar length and height was more on right sidethat is $(0.89 \mathrm{~cm} \& 1.77 \mathrm{~cm})$ respectively than that of left side $(0.80 \mathrm{~cm}$ \& $1.70 \mathrm{~cm}$ ) showing significant difference with p-value of $0.03 \& 0.01$ respectively (Table 5).

On the other hand, when anterior and posterior joint space were compared for right and left TMJ it was found that there was significant difference in anterior and posterior joint space of left TMJ with p-value of0.015. (Table 6)

In present study when shape of condyle was recorded it was observed that $3.8 \%$ shows round, $67 . \%$ convex and $29.2 \%$ had flat shape. (Table 7)

Table 1 - Description of the experimental design, techniques specifications of the materials used and treatment time

\begin{tabular}{|c|c|c|c|}
\hline Gender & $\mathbf{N}$ & Mean & Std.Deviation \\
\hline Male & 53 & 36.04 & 10.95 \\
\hline Female & 53 & 34.89 & 11.04 \\
\hline Total & 106 & 35.46 & 10.95 \\
\hline
\end{tabular}

Table 2 - Comparison of joint space between the genders

\begin{tabular}{|c|c|c|c|c|c|c|c|}
\hline \multirow{2}{*}{\multicolumn{2}{|c|}{ Joint space }} & \multirow{2}{*}{$\mathbf{N}$} & \multicolumn{2}{|c|}{ Male } & \multicolumn{2}{|c|}{ Female } & \multirow{2}{*}{$\begin{array}{c}\mathrm{p}- \\
\text { value }\end{array}$} \\
\hline & & & Mean & $\begin{array}{c}\text { Std. } \\
\text { Deviation }\end{array}$ & Mean & $\begin{array}{c}\text { Std. } \\
\text { Deviation }\end{array}$ & \\
\hline \multirow{3}{*}{ Right } & Superiorly & 53 & 0.30 & 0.05 & 0.28 & 0.03 & 0.758 \\
\hline & Anteriorly & 53 & 0.24 & 0.03 & 0.23 & 0.04 & 0.549 \\
\hline & Posteriorly & 53 & 0.25 & 0.05 & 0.22 & 0.04 & 0.997 \\
\hline \multirow{3}{*}{ Left } & Superiorly & 53 & 0.29 & 0.01 & 0.28 & 0.08 & 0.039 \\
\hline & Anteriorly & 53 & 0.24 & 0.03 & 0.23 & 0.03 & 0.488 \\
\hline & $\begin{array}{l}\text { Poste- } \\
\text { riorly }\end{array}$ & 53 & 0.24 & 0.03 & 0.22 & 0.03 & 0.714 \\
\hline
\end{tabular}

Table 3 - Comparison of joint space between the genders

\begin{tabular}{|c|c|c|c|c|c|c|c|}
\hline & & & & Male & & male & \\
\hline & & IN & Mean & $\begin{array}{c}\text { Std. } \\
\text { Deviation }\end{array}$ & Mean & $\begin{array}{c}\text { Std. } \\
\text { Deviation }\end{array}$ & value \\
\hline & Length & 53 & 0.91 & 0.10 & 0.87 & 0.10 & 0.163 \\
\hline & Width & 53 & 1.50 & 0.18 & 1.44 & 0.22 & 0.038 \\
\hline Right & Height & 53 & 1.83 & 0.21 & 1.70 & 0.20 & 0.881 \\
\hline & $\begin{array}{c}\text { Root } \\
\text { thickness }\end{array}$ & 53 & 0.23 & 0.05 & 0.21 & 0.04 & 0.177 \\
\hline & Length & 53 & 0.90 & 0.10 & 0.87 & 0.09 & 0.927 \\
\hline & Width & 53 & 1.47 & 0.17 & 1.44 & 0.24 & 0.024 \\
\hline Left & Height & 53 & 1.82 & 0.21 & 1.73 & 0.17 & 0.147 \\
\hline & $\begin{array}{c}\text { Root } \\
\text { thickness }\end{array}$ & 53 & 0.23 & 0.04 & 0.21 & 0.03 & 0.040 \\
\hline
\end{tabular}


Table 4 - Comparison of Joint Space Between Right \&Left side

\begin{tabular}{|c|c|c|c|c|c|c|}
\hline \multirow[b]{2}{*}{ Joint space } & \multirow{2}{*}{$\mathbf{N}$} & \multicolumn{2}{|c|}{ Right } & \multicolumn{2}{|c|}{ Left } & \multirow{2}{*}{ p-value } \\
\hline & & Mean & $\begin{array}{c}\text { Std. } \\
\text { Deviation }\end{array}$ & Mean & $\begin{array}{c}\text { Std. } \\
\text { Deviation }\end{array}$ & \\
\hline Superiorly & 106 & 0.24 & 0.06 & 0.27 & 0.02 & 0.078 \\
\hline Anteriorly & 106 & 0.20 & 0.01 & 0.23 & 0.04 & 0.069 \\
\hline Posteriorly & 106 & 0.16 & 0.05 & 0.21 & 0.01 & 0.04 \\
\hline
\end{tabular}

Table 5 - Comparison of Joint Morphology between the right and left side

\begin{tabular}{|c|c|c|c|c|c|c|}
\hline & \multirow[b]{2}{*}{$\mathbf{N}$} & \multicolumn{2}{|c|}{ Right } & \multicolumn{2}{|c|}{ Left } & \multirow[b]{2}{*}{ p-value } \\
\hline & & Mean & $\begin{array}{c}\text { Std. } \\
\text { Deviation }\end{array}$ & Mean & $\begin{array}{c}\text { Std. } \\
\text { Deviation }\end{array}$ & \\
\hline Length & 106 & 0.89 & 0.10 & 0.80 & 0.05 & 0.03 \\
\hline Width & 106 & 1.47 & 0.20 & 1.42 & 0.15 & 0.077 \\
\hline Height & 106 & 1.77 & 0.21 & 1.70 & 0.16 & 0.01 \\
\hline Root thickness & 106 & 0.22 & 0.04 & 0.17 & 0.01 & 0.096 \\
\hline
\end{tabular}

Table 6 - Comparison of Anterior and Posterior joint space between the right and left side

\begin{tabular}{cccccc} 
& & N & Mean & Std. Deviation & p-value \\
\multirow{2}{*}{ Right } & Anteriorly & 106 & 0.24 & 0.01 & \\
& Posteriorly & 106 & 0.16 & 0.04 & 0.081 \\
\multirow{2}{*}{ Left } & Anteriorly & 106 & 0.23 & 0.25 & \\
& Posteriorly & 106 & 0.20 & 0.03 & 0.015
\end{tabular}

Table 7 - Distribution of shapes between the right and left side

\begin{tabular}{|c|c|c|c|c|}
\hline \multirow{2}{*}{ Shape } & \multicolumn{2}{|c|}{ Right } & \multicolumn{2}{|c|}{ Left } \\
\hline & Frequency & Percent & Frequency & Percent \\
\hline Round & 4 & 3.8 & 4 & 3.8 \\
\hline Convex & 71 & 67.0 & 71 & 67.0 \\
\hline Flat & 31 & 29.2 & 31 & 29.2 \\
\hline Total & 106 & 100.0 & 106 & 100.0 \\
\hline
\end{tabular}

\section{DISCUSSION}

The mandibular condyle is one of the main sites of facial growth, which is expressed in an upward and backward direction. The appearance of mandibular condyle varies greatly among different age groups and individuals. In present study $36.8 \%$ changes are seen with condylar morphology in 40 to 50 years of age group ,32\% changes seen in 20 to 29 years of age group $28 \%$ changes are seen in 30 to 39 years of age group, which conformed the finding obtained by others. Human mandibular condyles may be categorized into five basic types: flattened, convex, angled, rounded and concave. Thus variability in the shapes and sizes of condyles should be an important factor in diagnosing the disorders of temporomandibular joint. [58]

Among various imaging modalities used for TMJ imaging, CT images are highly accurate for osseous abnormality. Cone-beam computed tomography images are superior over others for the bony morphology of mandibular condyles.

Our study had showed the most common shape of condyle $67 \%$ followed by flat $29.2 \%$ and only $2.8 \%$ found to be round. These observations were in contradictory to the studies conducted by Ribeiro EC et al. [59], Choudhary S et al. and Oliveira $\mathrm{C}$ et al. pertaining to the Brazilian and East Indian population respectively had shown that round/oval shape to be common. $[60,61]$

The relationship between gender and RGF thickness was discussed by Honda K, Ejima K, and Kijima N, all of them found that there was no significant difference in RGF thickness between males and females, but in present study there was a significant difference between roof thickness of males and females showing p-value of 0.040 . $[40,62,63]$ In our study, the value of superior joint space(SS) was the greatest in both sexes, followed by posterior joint space (PS) and anterior joint space(AS) respectively. This result is in agreement with the results of Ikeda K\& Kawamura A [9] , Dalili Z, [64], and Kinniburgh RD. [65] results agree with the results of our study that males have larger joint spaces than females especially the SS and PS. These larger joint spaces in males could possibly be explained by a greater soft tissue thickness. Condylar volume, width and height in males are larger than in females. $[64,65]$ 
Tadej G reported that overall size of the condyle in males was significantly larger than in females, probably due to the difference in overall sizeof the condyle between males and females in general, this might me because of masticatory habit. [26]

In this study, Roof thickness of glenoid fossa was more on right side $(0.22 \mathrm{~cm})$ as compaired to left side $(0.17 \mathrm{~cm})$ with no significant difference. This asymmetry could be related to normal cranial base asymmetries. The relationship between sides (right and left) and joint spaces (AS, SS and PS) was discussed by Wang R. [66] and Rodrigues AF. [67] They agreed that there was no significant difference between left and right sides .In present study we found that for AS and SS there was no significant difference between left and right sides but when PS was compared for right and left side there was significant difference with p-value of 0.04. Cohlmia JT. [34] suggested that the position of the condyle is asymmetric in a normal population.Blaschke DD\& Blaschke TJ. [68] found that there was a variation in condyle position in normal joints.

Condylar height, length, width and thickness of the roof of the glenoid fossa were significantly larger on the right side; there was no significant difference between left and right sides of condylar width and thickness of the roof of the glenoid fossa. Condylar length and hight shows significant difference between left and right sides ( $p$-value of 0.03 and 0.01). The condyle asymmetry between the right and left sides observed in the presence study could possibly be explained by the presence of a preferred side for mastication in subjects with malocclusion. [34]

\section{CONCLUSION}

The position of the condyle, thickness of RGF and the condyle size can be an indicator for variousTMJ joint diseases. Changes in morphology \& position of condylar head with glenoidfossa \& roof thickness are one of the most common cause for degenerative joint disease, disc perforation, disc displacement . It was observed that males exhibited a larger condyle size \& volume than females. In the assessment of symmetries between the condyles, they are asymmetrical and therefore eachcondyle must be evaluated separately. This information can be clinically useful in establishingthe diagnostic criteria for condylar size and position among the Indian population. A careful assessment of morphological changes of condylar head with CT cross-sectional imaging may serve this purpose.

In present study condylar width, height and roof thickness were different for Rt\& Left side. Shape of codyle was $67 \%$ convex, $29.2 \%$ flat \& $3.8 \%$ round condyle .Total 33\% shows morphological changes which is responsible for initiation of the internal derangement. Small asymmetries between left and right condyles seem to be common, but with no statistical significance.

Early diagnosis of morphological changes and bony changes help in proper treatment planning for TMD and prevent further damage to Temporomandibular joint.

\section{REFERENCES}

1. Neelimaanilmalik. Textbook of oral and maxillofacial surgery. 2 ed. India: Jaypee brothers. 2008. p 226-239.

2. SMBalaji. Textbook of oral and maxillofacial surgery. 2 ed. India: Elsevier. 2013. p 31-52.

3. Zarb GA, Carlsson GE. Osteoarthrosis/osteoarthritis. In: Zarb GE, Carlsson GE, Sessle BJ, Mohl ND (eds). Tempromandibular joint and Masticatory Muscle Disorders. Copenhagen: Munksgaard, 1994:298-314

4. Katsavrias EG, Halazonetis DJ. Condyle and fossa shape in Class II and Class III skeletal patterns: A morphometric tomographic study. Am J Orthod Dentofacial Orthop. 2005 Sep;128(3):337-46.

5. Katsavrias EG. Morphology of the Temporomandibular joint in subjects with Class II Division 2 malocclusions. Am J Orthod Dentofacial Orthop. 2006 Apr;129(4):470-8.

6. Barrera-Mora JM, Espinar Escalona E, Abalos Labruzzi C, Llamas Carrera JM, Ballesteros EJ, Solano Reina E, et al. The relationship between malocclusion, benign joint hypermobility syndrome, condylar position and TMD symptoms. Cranio. 2012;30(2):121-30. doi:10.1179/crn.2012.018

7. Kurusu A, Horiuchi M, Soma K. Relationship between occlusal force and mandibular condyle morphology. Evaluated by limited cone-beam computed tomography. Angle Orthod. 2009;79(6):1063-9. doi:10.2319/120908-620R.1.

8. Pullinger AG, Hollender L, Solberg WK, Petersson A. A tomografic study of mandibular condyle position in an asymptomatic population. J Prosthet Dent. 1985;53(5):706-13. 
9. Ikeda K, Kawamura A. Assessment of optimal condylar position with limited cone-beam computed tomography. Am J Orthod Dentofacial Orthop. 2009 Apr;135(4):495-501. doi:10.1016/j.ajodo.2007.05.021.

10. Pullinger AG, Solberg WK, Hollender L, Petersson A. Relationship of mandibular condylar positon to dental occlusion factors in an asymptomatic population. Am J Orthod Dentofacial Orthop. 1987 Mar;91(3):200-6.

11. Bonilla-Aragon H, Tallents RT, Katzberg RW, Yrkanides S, Moss ME. Condyle position as a predictor of Temporomandibular joint internal derangement. J Prosthet Dent. 1999 Aug;82(2):205-8.

12. Vitral RW, Campos MJS, Rodrigues AF, Fraga MR. Temporomandibular joint and normal occlusion: Is there anything singular about it? A computed tomographic evaluation. Am J Orthod Dentofacial Orthop. 2011 Jul;140(1):1824. doi: 10.1016/j.ajodo.2009.07.030.

13. Kinzinger G, Kober C, Diedrich P. Topography and morphology of the mandibular condyle during fixed functional orthopedic treatment - a magnetic resonance imaging study. J Orofac Orthop. 2007 Mar;68(2):124-47. doi:10.1007/s00056-007-0650-0

14. Krisjane Z, Urtane I, Krumina G,Zepa K. Three-dimensional evaluation of TMJ parameters in Class II and Class III patients. Stomatologija. 2009;11(1):32-6.

15. Rodrigues AF, Fraga MR, Vitral RWF.Computed tomography evaluation of the temporomandibular joint in Class I malocclusion patients: condylar symmetry and condyle-fossa relationship. Am J Orthod Dentofacial Orthop. 2009 Aug;136(2):192-8. doi: 10.1016/j.ajodo.2007.07.032.

16. Vitral RW, Telles CS. Computed tomography evaluation of temporomandibular joint alterations in Class III Division 1 subdivision patients: condylar symmetry. Am J Orthod Dentofacial Orthop. 2002 Apr;121(4):369-75.

17. Blasberg B, Greenberg MS. Temporomandibular disorders. In: Greenberg MS Glick M, Ship JA. Burket's oral medicine. 11 ed. PMPH-USA: 2008. 224-229.

18. Ross BR, Johnston MC. Developmental anomalies and dysfunction. In: Zarb GA, Carlsson GE, Sessle BJ, Mohl ND (eds). Temporomandibular joint and masticatory muscle disorders. Mosby: 1994. p221-222.

19. Standring S. Gray's anatomy the anatomical basis of clinical practice. $39 \mathrm{ed}$. Elsevier Ltd:2005. p 519-530.

20. Alomar X, Medrano J, Cabratosa J, Clavero JA, Lorente M, Serral, et al. Anatomy of temporomanidular joint. Seminars in Ultrasound CT and MRI. 2007 Jun;28(3):170-83.

21. Neto JV, Estrela C, Bueno MR, Guedes OA, Porto OCL, Pecora JD. Mandibular condyle dimensional changes in subjects from 3 to 20 years of age using Cone-Beam Computed Tomography: A preliminary study. Dental Press J Orthod. 2010;15(5):172-81.

22. Yale SH, Rosenberg HM, Ceballos M, Haupt-Fuehrer JD. Laminagraphic cephalometry in the analysis of mandibular condyle morphology. A preliminary report. Oral Surg Oral Med Oral Pathol. 1961 Jul;14:793-805.

23. Yale SH, Ceballos M, Kresnoff CS, Hauptfuehrer JD. Some observation on the classification of mandibular condyle types. Oral Surg Oral Med Oral Pathol. 1963 May;16:572-7.

24. Goncalves N, Miller AM, Yale SH, Rosenberg HM, Hauptfuehrer JD. Radiographic evaluation of defects created in mandibular condyles. Oral Surg Oral Med Oral Pathol. 1974 Sep;38(3):474-89.

25. Yale SH, Allison BD, Hauptfuehrer JD. An epidermiological assessment of mandibular condyle morphology. Oral Surg Oral Med Oral Pathol. 1966 Feb;21(2):169-77.
26. Tadej G, Engstrom C,Borrman H,Christian EL. Mandibular condyle morphology in relation to malocclusion in children. Angle Orthod. 1989 Fall;:59(3):187-94.

27. Ueda M, Yonetsu K, Ohki M, Yamada T, Kitamori H, Nakamura T.Curvature analysis of the mandibular condyle. Dentomaxillofac Radiol. 2003 Mar;32(2):87-92

28. Crawford SD. Condylar axis position, as determined by the occlusion and measured by the CPI instrument, and signs and symptoms of temporomandibular dysfunction. Angle Orthod. 1999 Apr;69(2):103-15; discussion 115-6.

29. Myers DR, Barenie JT, Bell RA, Williamson EH. Condylar position in children with functional posterior crossbite: before and after crossbites correction. Pediatr Dent. 1980 Sep;2(3):190-4.

30. Pullinger AG, Solberg WK, Hollender L, Petersson A. Relationship of mandibular condylar position to dental occlusion factors in an asymptomatic population. Am J Orthod Dentofacial Orthop. 1987 Mar;91(3):200-6.

31. O'Byrn BL, Sadowsky C, Schneider B, Beole EA. An evaluation of mandibular asymmetry in adults with unilateral posterior crossbite. Am J Orthod Dentofacial Orthop. 1995 Apr;107(4):394-400.

32. Schudy FF. Treatment of adult midline deviation by condylar repositioning. $J$ Clin Orthod. 1996 Jun;30(6):343-7.

33. Stamm T, Hohoff A, Van Meegen A, Meyer U. On the threedimensional physiological position of the temporomandibular joint. J Orofac Orthop 2004:65(4):280-9.

34. Cohlmia JT, Ghosh J, Sinha PK, Nanda RS, Currier GF. Tomographic assessment of temporomandibular joints in patients with malocclusion. Angle Orthod. 1996;66(1):27-35.

35. Langberg BJ, Arai K, Miner RM. Transverse skeletal and dental asymmetry in adults with unilateral lingual posterior crossbite. Am J Orthod Dentofacial Orthop. 2005 Jan;127(1):6-15; discussion 15-6.

36. White S, Pharoah MJ. Oral Radiology Principles and Interpretation. 6 ed. Mosby Elsevier:2009.

37. Pandis N, Karpac J, Trevino R, Williams B. A radiographic study of condyle position at various depths of cut in dry skulls with axially corrected lateral tomograms. Am J Orthod Dentofacial Orthop. 1991 Aug;100(2):116-22.

38. Katsavrias $\mathrm{EG}$. Changes in articular eminence inclination during the craniofacial growth period. Angle Orthod. 2002 Jun;72(3):258-64.

39. Ejima K, Schulze D, Stippig A, Matsumoto K, Rottke D, Honda K. Relationship between the thickness of the roof of glenoid fossa, condyle morphology and remaining teeth in asymptomatic European patients based on cone beam CT data sets. Dentomaxillofac Radiol. 2013;42(3):90929410. doi: 10.1259/ dmfr/90929410. Epub 2012 Sep 20.

40. Honda K, Kawashima S, Kashima M, Sawada K, Shinoda K, Sugisaki M Relationship between sex, age, and the minimum thickness of the roof of the glenoid fossa in normal temporomandibular joints. Clin Anat. 2005 Jan;18(1):23-6.

41. Kijima N, Honda K, Kuroki Y, Sakabe J, Ejima K, Nakajima I. Relationship between patient characteristics,mandibular head morphology and thickness of the roof of the glenoid fossa in symptomatic temporomandibular joints. Dentomaxillofac Radiol. 2007 Jul;36(5):277-81.

42. Tsuruta A, Yamada K, Hanada K, Hosogai A, Tanaka R, Koyama J, et al. Thickness of the roof of the glenoid fossa and condylar bone change: $\mathrm{CCT}$ study. Dentomaxillofac Radiol. 2003 Jul;32(4):217-21. 
43. Wu CK, Hsu JT, Shen YW, Chen JH, Shen WC, Fuh LJ. Assessments of inclinations of the mandibular fossa by computed tomography in an Asian population. Clin Oral Investig. 2012 Apr;16(2):443-50. doi: 10.1007/s00784-0110518-y. Epub 2011Feb 12.

44. Som PH, Curtin HD. Head and Neck Imaging. 5 ed. Elsevier Health Sciences: 2011.

45. White SC, Pharoah MJ. Oral Radiology: Principles and Interpretation. 6 ed Elsevier Health Sciences: 2009.

46. Ricketts RM. Variations of the temporomandibular joint as revealed by cephalometric laminagraphy. Am J Orthod. 1950 Dec;36(12):877-98.

47. Cho BH, Jung YH. Osteoarthritic changes and condylar positioning of the temporomandibular joint in Korean children and adolescents. Imaging Sci Dent. 2012 Sep;42(3):169-74. doi: 10.5624/isd.2012.42.3.169. Epub2012 Sep 21.

48. Weinberg LA. An evaluation of occlusal factors in TMJ dysfunction-pain syndrome. JProsthet Dent. 1979 Feb;41(2):198-208.

49. Weinberg LA. Correlation of temporomandibular dysfunction with radiographic findings. J Prosthet Dent. 1972 Nov;28(5):519-39.

50. Blaschke DD, Solberg WK, Sanders B. Arthorgraphy of the temporomandibular joint: review of current status. J Am Dent Assoc. 1980 Mar;100(3):388-95

51. Farrar WB, McCarthy WL Jr. Conventional radiography compared with arthrography in internal derangements of the temporomandibular joint. $J$ Prosthet Dent. 19830ct;50(4):585-6.

52. Mongini F. Combined method to determine the therapeutic position for occlusal rehabilitation. J Prosthet Dent. 1982 Apr;47(4):434-9.

53. Weinberg LA. Definitive prosthodontic therapy for TMJ patients. Part I:Anterior and posterior condylar displacement. JProsthet Dent. 1983 0ct:50(4):544-57.

54. Herbosa EG, Rotskoff KS, Ramos BF, Ambrookian HS. Condylar position in superior maxillary repositioning and its effect on the temporomandibular joint. J Oral Maxillofac Surg. 1990 Jul;48(7):690-6

55. O'Ryan F, Epker BN. Surgical orthodontics and the temporomandibular joint. I. Superior repositioning of the maxilla. Am J Orthod. 1983 May;83(5):408-17.

56. Hilgers ML, Scarfe WC, Scheetz JP,Farman AG. Accuracy of linear temporomandibular joint measurements with cone beam computed tomography and digital cephalometric radiography. Am J Orthod Dentofacial Orthop. 2005 Dec;128(6):803-11.

57. Kai Y, Matsumoto K, Ejima K, Araki M, Yonehara Y,Honda K. Evaluation of the usefulness of magnetic resonance imaging in the assessment of the thickness of the roof of the glenoid fossa of the Temporomandibular joint.
Oral Surg Oral Med Oral Pathol Oral Radiol Endod. 20110ct;112(4):508-14. doi: 10.1016/j.triple0.2011.05.013. Epub 2011 Aug 19.

58. Hegde S, Praveen BN, Shetty SR. Morphological and Radiological Variations of Mandibular Condyles in Health and Diseases: A Systematic Review. Dentistry. 2013;3(1):154. doi:10.4172/2161-1122.1000154.

59. Ribeiro EC, Sanches ML, Alonso LG, Smith RL. Shape and symmetry of human condyle and mandibular fossa. Int J Odontostomat. 2015;9(1):65-72.

60. Chaudhary S, Srivastava D, Jaetli V, Tirth A. Evaluation of condylar morphology using panoramic radiography in normal adult population. Int J Sci Stud. 2015;2(11):164-8.

61. Oliveira C, Bernardo RT, Capelozza AA. Mandibular condyle morphology on panoramic radiographs of asymptomatic Temporomandibular joints. Int $\mathrm{J}$ Dent 2009;8(3):114-8.

62. Ejima K, Schulze D, Stippig A, Matsumoto K, Rottke D, Honda K. Relationship between the thickness of the roof of glenoid fossa, condyle morphology and remaining teeth in asymptomatic European patients based on cone beam CT data sets. Dentomaxillofac Radiol. 2013;42(3):90929410. doi: 10.1259/ dmfr/90929410. Epub 2012 Sep 20.

63. Kijima N, Honda K, Kuroki Y, Sakabe J, Ejima K, Nakajima I. Relationship between patient characteristics, mandibular head morphology and thickness of the roof of the glenoid fossa in symptomatic Temporomandibular joints. Dentomaxillofac Radiol. 2007 Jul;36(5):277-81.

64. Dalili Z, Khaki N, Kia SJ, Salamat F. Assessing joint space and condyla position in the people with normal function of temporomandibular joint with cone-beam computed tomography. Dent Res J (Isfahan). 2012 Sep;9(5):60712.

65. Kinniburgh RD, Major PW, Nebbe B, West K, Glover KE. Osseous morphology and spatial relationships of the temporomandibular joint: comparisons of normal and anterior disc positions. Angle 0rthod. 2000 Feb;70(1):70-80.

66. Wang R, Ma X, Zhang W, Liu D. Investigation of temporomandibular joint space of healthy adults by using cone beam computed tomography. Beijing Da Xue Xue Bao Yi Xue Ban. 2007 0ct 18;39(5):503-6.

67. Rodrigues AF, Fraga MR, Vitral RW. Computed tomography evaluation of the temporomandibular joint in Class II Division 1 and Class III malocclusion patients: condylar symmetry and condyle-fossa relationship. Am J Orthod Dentofacial Orthop. 2009 Aug;136(2):199-206. doi:10.1016/j. ajodo.2007.07.033.

68. Blaschke DD, Blaschke TJ. A method for quantitatively determining temporomandibular joint bony relationships. J Dent Res. 1981 Jan;60(1):3543.

Dr.Shivlal. M.Rawlani

(Corresponding address)

Associate Professor

Dept. of Oral Medicine \& Radiology, Sharad Pawar dental

College\& Hospital

DMIMS-U, Sawangi (M), Wardha, Maharashtra, India

Date submitted: 2017 0ct 16

E-mail - drrawlani2007@rediffmail.com Accept submission: 2018 Feb 28 